\title{
Alternative Trade Strategies and Employment in LDCs: An Overview
}

\author{
ANNE O. KRUEGER ${ }^{*}$
}

This paper reviews the theoretical and empirical evidence about interactions between trade policy instruments and domestic factor markets and their role in affecting the labour intensity of industry mix and choice of techniques in a number of developing countries. Using estimates of the elasticities of substitution in the manufacturing sector, statistical evidence is presented to determine the impact of trade policy on industrial employment. There is a strong presumption that the phenomena under review were mainly responsible for low rates of employment grow th in the industrial sector in those countries where distortions were sizeable.

The National Bureau of Economic Research's project on Alternative Trade Strategies and Employment was designed to investigate the relationship between choice of trade strategy, domestic factor markets, and the rate of growth of nonagricultural employment. This paper summarizes some of the main results.

Three alternative, mutually inconsistent, hypotheses were all possible:

(1) The amount of employment generated is relatively independent of the trade strategy;

(2) Import substitution generates significantly less employment growth than does an export-oriented strategy; ${ }^{1}$ and

(3) An export-promotion strategy may in fact conflict with efforts to expand employment.

The first possibility - that trade strategy does not affect employment very much - might arise for several reasons. First, one might be able to establish the

The author is Professor of Economics at the University of Minnesota, Minneapolis, Minn. (USA). This paper summarizes some of the results of the National Bureau of Economic Research (NBER) research project on Alternative Trade Strategies and Employment. A full account of the research may be found in $[5 ; 6 ; 7]$.

${ }^{1}$ By export-oriented trade strategy is meant a set of policies which are designed to induce exports, without regard to the specific product exported. In general, such a strategy is infeasible if high levels of protection are accorded to other industries in the economy. 
direction of difference in labour intensity of poduction, but find that the difference, if any, was so small that, within the conceivable range of relative growth rates, the effects on employment would be second-order small. Secondly, one might find that a particular policy (such as subsidization of capital-goods imports), not really essential to the trade strategy adopted, had adverse effects on employment and that a different set of policies could implement the same trade strategy without the adverse employment effects. Finally, it might be that the influences determining the composition of exporting and import-substitution industries are independent of factor intensities, and that different relative rates of growth of the two groups of industries would not necessarily affect the rate of growth of employment.

The second possibility - that import-substitution industries require considerably less labour per unit of capital and per unit of value added - is the forecast that would arise from straightforward interpretation of the two-factor Heckscher-Ohlin model of trade. Developing countries would presumably have their comparative advantage, at least in the early stages of growth, in exporting labour-intensive commodities and importing goods with relatively higher capital (and perhaps skilled laboùr) requirements.

Finally, there is the already-mentioned possibility that export promotion and employment growth are conflicting objectives. Several possible reasons have been suggested. One view was that developed countries have erected, or would erect if export-promotion strategies were adopted, such high barriers to import of labourintensive goods that the developing countries can only compete in capital-intensive exports. Another argument was of the casual empiricism suggesting that the exports of some developing countries - notably Colombia and Brazil - were capital-intensive. Yet others claimed that most of the exports of manufactured goods originating in developing countries are produced by branches and subsidiaries of multinational corporations which, it was alleged, use capital-intensive technology of the home country.

If export-promoting growth was capital-intensive, there remained a question as to why it was so: the answer might lie partly in the mix of export incentives granted in the developing country and in domestic policies affecting the relative profitability of different industries. If, instead, developing countries' potential manufactured export were capital-intensive, not because of distortions but because of factors associated with comparative advantage, it was important to ascertain it and to obtain some idea of the empirical magnitude and importance of the phenomenon.

\section{THE EMPLOYMENT “PROBLEM” IN THE LDCS}

Everyone agrees that employment is a "problem" and that increased employment opportunities are an "objective" in most LDCs. There is less agreement, however, as to what the nature and cause of the "problem" are and as to the reason why employment creation is desirable.
In part, this is because the reasons for concern differ from country to country. They include (i) increasing relatively high-productivity employment opportunities outside the agricultural sector to absorb the low-income agricultural population; (ii) increasing employment opportunities in the urban sector to reduce the number of the urban unemployed; and (iii) providing employment opportunities for the poor in order to increase their real income and improve the distribution of income.

The first concern has been a focal point of development economics ever since. W. Arthur Lewis's classic article, "Economic Development with Unlimited Supplies of Labour". Lewis characterized the development process as being that of creating higher-product non-agricultural employment opportunities at a sufficiently rapid rate first to increase the share of the labour force in non-agricultural activities and then to decrease absolutely the number of persons engaged in agriculture.

Although Lewis's analysis led to the view that there was "disguised unemployment" in agriculture, positing a zero marginal product of labour in agriculture was not really central to his analysis. Rather, the central insight was that additional nonagricultural employment opportunities would raise real income by transferring persons from low-wage, low-product employment to higher-wage, higher-product employment. Seen in this light, Lewis's concern with the employment problem was that of increasing the productivity associated with the employment activities of the population.

Although subsequent developments have indicated forcefully that there are many opportunities for increasing real output and income within agriculture, to this day a central reason for concern with employment creation is the belief that raising the average and marginal product of the entire labour force is crucial to the growth process. Emphasis is placed upon non-agricultural employment opportunities, largely because it is believed that, given pressures of population growth on the land, non-agricultural employment opportunities will (in conjunction with output increases in the agricultural sector) provide the best means for increasing real income, and thereby raising the rate of growth of per capita incomes. ${ }^{2}$

Concern with absorbing the urban unemployed focuses more specifically upon the social hardships associated with unemployment in the cities. It is well known that urban populations have increased very rapidly in most of the developing countries in the past several decades. In many countries, that growth has been accompanied by an increasing number of the urban unemployed, while the rate of increase in employment opportunities, at least in the "formal" sector of the

${ }^{2}$ There are two sets of models that posit an upper bound on the number of "productive" jobs that can be created. The first is the "technological" explanation, first set forth by Eckaus [2]. According to that view, the labour-capital endowment in the industrial sector of developing countries exceeds the maximum technologically feasible ratio. The alternative is the "two-gap" The model is associated with Hollis B. Chenery and Michael Bruno [1]. 
economy, has been sluggish. Creation of urban employment has been regarded as a desirable policy goal because of the belief that this would reduce urban unemployment and its accompanying hardships. ${ }^{3}$

The third concern, providing employment opportunities to the poor, has somewhat different origins. Unlike Lewis's focus, in which employment creation is associated with economic growth and rising per capita real incomes, the objective has been redistribution rather than growth. This focus explicitly raises the question of the extent to which "employment creation" is compatible with economic growth; in other words, whether providing more jobs, instead, may not lower the rate of economic growth.

Conflict would arise, of course, only if job creation meant reducing real output, or if creating more jobs with given investible resources implied achieving a lower increment in real output rather than creating fewer jobs with those same resources. In so far as policies can be identified which would permit a faster rate of increase in employment (especially of the unskilled) with efficient allocation of resources, everyone would agree on the preferability of those job opportunities to ones that reduced real income and output. It is therefore safe to conclude that if a trade strategy that is optimal from the viewpoint of resource allocation also creates (in the sense to be defined below) as many new job opportunities as (or more such opportunities the than) a non-optimal one, the question of "conflict" between real income and employment does not arise.

In the NBER project, focus on the link between trade strategies and employment was centred upon the non-agricultural, and often the industrial, sector. This was done partly because it was believed that rapid rates of non-agricultural labour force growth made this the pressing policy issue, and partly because it was believed that the key links between choice of trade strategy and employment arise in the industrial sector of developing countries. Suffice it here to point out that this focus is consistent with many views of rural labour markets, including the Lewis viewpoint, and also with the notion that rapidly growing populations must, if per capita incomes are to rise, find productive non-agricultural employment.

There is yet another issue, which has to do with what is meant by "job creation," and what the determinants of (non-agricultural) employment and its growth rate are. If labour markets in developing countries functioned well in the neoclassical sense, the "employment problem" would centre entirely upon the set of concerns related to productivity and shifting the demand for labour upward. Outward shifts in the demand for labour in excess of the rate of outward shift of supply (due to population growth and consequent changes in the labour force) would result in rising real wages, since, by hypothesis, in a well-functioning market all would be employed at a similar wage. ${ }^{4}$ Failure to shift the demand curve for labour

${ }^{3}$ Depending upon the structure of the urban labour market, creating more jobs may in fact Dee Harris and Todaro [3].

${ }^{4}$ For an analysis of the role of skills and determinants of the wage structure, see below. outward rapidly enough would result, not in unemployment, but rather in a decline in the real wage. ${ }^{5}$ This provides the motive for concern with shifting the demand for labour outward, which has been the interpretation placed on "employment" in the NBER project.

However, there are important questions about the determinants of the labour supply to non-rural areas, ${ }^{6}$ the degree to which labour markets are fragmented or integrated, ${ }^{7}$ and non-market influences upon the level and structure of wages. Open unemployment in urban areas has emerged as a major policy problem in some countries and consideration of the "employment problem" requires a satisfactory analysis of why unemployment exists, who the unemployed are, and what their resources are

For purposes of analyzing the relation between trade strategies and employment, the presence of open urban unemployment must give the analyst a pause. In particular, under some kinds of market imperfections, outward shifts in the demand for labour can generate responses that largely, if not entirely, offset any increase in employment that might otherwise result. This can be seen with two simple examples. If labour markets are sufficiently fragmented, outward shifts in deman for labour in some parts of the market may not result in additional employment but, instead, raise wages for those already employed in the sector. Likewise, if unions are sufficiently powerful so that all outward shifts in the demand for labour in unionize sectors are fully offset by increased real wages, policies designed to create jobs in the high-productivity unionized sectors are destined to frustration.

Thus, in interpreting data on labour coefficients and average wage rates, the analyst must ascertain whether labour coefficients reflect distortions rather than the inherent "labour intensities" that would be observed in a competitive labour market. Observed trade patterns may be influenced by the existing pattern of wages and may not reflect comparative advantage that would exist under an efficient allocation of resources. Finally, identifying the impact that alternative trade strategies might have upon the demand for labour cannot be equated with its impact on employment when some sorts of distortions are present.

\section{ALTERNATIVE TRADE STRATEGIES}

A necessary condition for optimal resource allocation for any country is that the domestic marginal rate of transformation (DMRT) among produced

${ }^{5} \mathrm{It}$ is even possible that in a neoclassical labour market an upward shift in the demand for labour could result in decreased employment (if the labour supply curve were backwardlabour could
bending).

${ }^{6}$ See Sen $[10]$ for a fuller discussion of the ways in which the labour supply to the urban sector might be perfectly elastic.

${ }^{7}$ The less the degree to which changes in one part of a market affect other parts, the more fragmented that market is said to be. If labour is perfectly immobile between two areas, their markets are entirely fragmented. 
commodities should equal the international marginal rate of transformation (IMRT) among them. For a small country unable to influence its international terms of trade, international prices (f.o.b. for export and c.i.f. for import) ${ }^{8}$ can be used to reflect IMRTs. In the absence of distortions in the domestic market, domestic prices can be used to reflect DMRTs. ${ }^{9}$

It is readily shown that any departure from this optimality rule results in a production cost to the economy: when the DMRT between a pair of traded commodities is unequal to the IMRT, switching production toward the item with the relatively lower domestic cost enables a country to receive more of the other commodity through trade than it can obtain through domestic production.

The optimality criterion leads naturally to a definition of bias of alternative trade regimes: bias defines the direction and the degree to which, on an average, domestic incentives diverge from those that would prevail under free trade. The notion is most readily formalized in the two-commodity case. Let p's represent international prices, and q's domestic prices, with subscripts $\mathrm{m}$ and $\mathrm{x}$ denoting the import-competing and export goods respectively. Then, B, the bias of the regime, can be defined simply as:

$$
B=\frac{\frac{\mathrm{q}_{\mathrm{m}}}{\mathrm{p}_{\mathrm{m}}}}{\frac{\mathrm{q}_{\mathrm{x}}}{\mathrm{p}_{\mathrm{x}}}}
$$

If the world and domestic prices of exportables coincide, while the domestic price of import-competing goods is above the world price, $\mathrm{B}>1$ and the regime is biased towards import substitution. Conversely, if imports are subsidized, then $\mathrm{B}<1$ and the bias of the regime is toward exports. Naturally, the more B diverges from unity in a particular direction, the more biased the regime is.

One might anticipate that countries would stay fairly close to uniform incentives. In practice, while even the most import-substitution-oriented countries

${ }^{8}$ There is a range of commodities whose allocation to export or import categories is ambiguous, and the precept that is so simple in theory is not that readily implemented in practice. See [5, Chap. 1] for a discussion of the allocation of commodities and industries to trade categories on the basis of the conceptual framwork of Chapter 4, in [7]

${ }^{9}$ In the presence of such distortions, shadow prices can be used to estimate DMRTs. Estimation itself is difficult empirically, although conceptually it is straightforward. See T. N. Srinivasan and Jagdish Bhagwati [11] for a discussion. encourage some exportable industries (at least more than others) and export-promotion countries normally protect some import-substitution industries, one rarely encounters a bias of around unity in trade regimes with some high levels of protection for import-competing industries and some large incentives for export promotion. Regimes tend either to be generally biased towards import substitution or towards export promotion.

\section{COUNTRIES COVERED IN THE PROJECT}

Table 1 indicates the countries covered by the project and, in addition, gives some data which provide insight into some aspects of the trade regime in those countries. Estimates are given of the mean effective rate of protection (ERP) for all manufacturing activities for sale in the home market in the year indicated. In the third column, the abbreviations give a rough idea of the trade strategy in force at the time of the ERP estimates. Several of the countries altered their trade strategies, so that additional inferences could be drawn from their experience.

\section{DIFFERENCES IN LABOUR COEFFICIENTS}

Observed labour coefficients are the joint outcome of underlying comparative advantage, the incentives accorded by the trade regime, and conditions in domestic factor markets. Table 2 gives estimates of labour inputs per unit of DVA (domestic value added) in various exportable trade categories expressed as a ratio of the labour per unit of DVA in Heckscher-Ohlin-Samuelson (HOS) import-competing industries. ${ }^{10}$ For Brazil, for example, the average labour input per unit of DVA in HOS exportables was 2.07 times as much as the labour input per unit of DVA in importcompeting activities.

The second and the third columns give comparable estimates, again as a ratio to the figure for import-competing industries, for non-primary-commodity-based HOS exportables and (primary-commodity based) PCB-HOS exportables separately. A final column gives estimates, for those countries for which they are available, of the labour coefficients for NRB exportables. ${ }^{11}$

${ }^{10} \mathrm{HOS}$ industries are manufacturing industries; the classification into exportable and import-competing was made by each country author based on criteria spelled out in [5, Chap. 1].

${ }^{11}$ The Ivorian estimates provide an indication of some of the complexities of attempting to associate particular groups of industries with alternative trade strategies. In that country, natural-resource-based (NRB) exports have predominated. For those commodities, "artisanal" labour is employed, and expansion of NRB exports (and NRB import-competing production) would entail increased demand for artisanal labour (some of which comes from immigration from neighbouring countries). Artisanal labour is naturally unskilled and most NRB export activities are highly labour-intensive. Contrasting the labour coefficients for NRB exports with that for total labour in all HOS import-competing activities shows that NRB exports with more than nine times as much labour per unit of domestic value added [7, Chap. 5] and [5, Chap. 6]. 
It is of interest that in all countries, except Chile, total HOS exports had labour coefficients per DVA that exceeded those in the corresponding import-competing sectors. In the Chilean case, pulp and paper is a significant component of HOS

Table 1

Indicators of Trade Strategy: Various Countries

\begin{tabular}{|c|c|c|c|c|c|c|}
\hline Countries & Period & $\begin{array}{c}\text { Trade } \\
\text { Strategy }\end{array}$ & $\begin{array}{c}\text { Average ERP } \\
\text { for Manufacturing }\end{array}$ & \multicolumn{3}{|c|}{$\begin{array}{l}\text { Range } \\
\text { of ERPs }\end{array}$} \\
\hline (1) & (2) & (3) & (4) & \multicolumn{3}{|c|}{ (5) } \\
\hline Argentina & 1969 & IS & 111 & -13 & to & 900 \\
\hline \multirow[t]{3}{*}{ Brazil } & 1958 & IS & 106 & 17 & to & 502 \\
\hline & 1963 & IS & 184 & 60 & to & 687 \\
\hline & 1967 & MIS & 63 & 4 & to & 252 \\
\hline Chile & 1967 & IS & 175 & -23 & to & 1140 \\
\hline Colombia & 1969 & MIS & 19 & -8 & to & 140 \\
\hline Hong Kong & 1972 & EP & 1 & & sma & \\
\hline Indonesia & 1971 & MIS & 119 & -19 & to & 5400 \\
\hline Ivory Coast & 1973 & EP & 41 & -25 & to & 278 \\
\hline \multirow[t]{2}{*}{ Pakistan } & $1963-64$ & IS & 356 & -6 & to & 595 \\
\hline & $1970-71$ & IS & 200 & 36 & to & 595 \\
\hline South Korea & 1968 & EP & -1 & -15 & to & 82 \\
\hline Thailand & 1973 & MIS & 27 & -43 & to & 236 \\
\hline Tunisia & 1972 & IS & 250 & 1 & to & 737 \\
\hline Uruguay & 1965 & IS & 384 & 17 & to & 1014 \\
\hline
\end{tabular}

Notes: $\quad \mathrm{EP}=$ export promotion.

$\begin{aligned} \text { IS } & =\text { import substitution. } \\ \text { MIS } & =\text { moderate import substitution. }\end{aligned}$

Argentina: Julio Nogues, Banco Central de Argentina,

Brazil: Jose L. Carvalho, Fundacao Getulio Vargas - EPGE,

Chile: Vittorio Corbo, Universidad de Chile and Patricio Meller, CIEPLAN,

Colombia: Francisco E. Thoumi, Inter-American Development Bank,

Hong Kong: Yun Wing Sung, Chinese University of Hong Kong,

Indonesia: Mark M. Pitt, University of Minnesota,

Ivory Coast: Terry Monson, Michigan Technological University,

$\begin{array}{ll}\text { Ivory Coast: } & \text { Terry Monson, Michigan Technological University } \\ \text { Pakistan: } & \text { Stephen Guisinger, University of Texas at Dallas, }\end{array}$

$\begin{array}{ll}\text { Pakistan: } & \text { Stephen Guisinger, University of } \\ \text { South Korea: } & \text { Wontack Hong, Seoul University, }\end{array}$

South Korea: Wontack Hong, Seoul University,

$\begin{array}{ll}\text { Thailand: } & \text { Narongchai Akrasanee, Asian and Pacific Develop } \\ \text { Tunisia: } & \text { Mustapha K. Nabli, Campus Universitaire, Tunis, }\end{array}$

Tunisia: Mustapha K. Nabli, Campus Universitaire, Tunis,

Uruguay: $\quad$ Alberto Bension and Jorge Caumont, Universidad de la Republica, Montevideo.

Except for Argentina and Hong Kong, the results for individual countries may be found in the individual country chapters in [5]. Argentinian results are in Julio Nogues [9] and Hong Kong in Yung Wing Sung [12]. exports; when pulp and paper was treated as a PCB-HOS industry, Chilean and other HOS manufactures required 1.5 times as much labour as Chilean import-competing HOS activities. The differences between labour coefficients for total HOS exports and HOS import-competing industries are sizable for many of the countries, exceeding a factor of two for Brazil, Indonesia, and Thailand, and also exceeding that number in Tunisia when PCB-based manufacturing is excluded.

Table 2

\section{Direct Labour Coefficients per Unit of DVA \\ (ratio of coefficients in designated \\ trade category to coefficients in \\ HOS import-competing activities)}

\begin{tabular}{cccc}
\hline & \multicolumn{3}{c}{ HOS Exports } \\
\cline { 2 - 3 } Countries & NRB \\
(with Reference Years) & $\begin{array}{c}\text { Manufactures } \\
\text { not PCB }\end{array}$ & $\begin{array}{c}\text { PCB } \\
\text { Eanufactures }\end{array}$ & Total \\
\hline
\end{tabular}

(1)

(2)

(3)

(4)

(5)

\begin{tabular}{llllll}
\hline Argentina & $(1963)$ & n.a. & n.a. & 1.24 & n.a. \\
& $(1973)$ & n.a. & n.a. & 1.30 & n.a. \\
Brazil & $(1970)$ & n.a. & n.a. & 2.07 & 2.02 \\
Chile & $(1966-68)$ & 1.50 & n.a. & 0.80 & n.a. \\
Colombia & $(1973)$ & n.a. & n.a. & 1.88 & n.a. \\
Indonesia & $(1971)$ & 1.58 & n.a. & 2.09 & n.a. \\
Ivory Coast & $(1972)$ & & & & \\
(a) modern sector & & n.a. & n.a. & 1.35 & 2.28 \\
(b) total & & n.a. & n.a. & 1.16 & 9.04 \\
Pakistan & $(1969-70)$ & 1.23 & 1.69 & 1.42 & n.a. \\
South Korea & $(1968)$ & n.a. & n.a. & 1.00 & n.a. \\
Thailand & $(1973)$ & 3.20 & 1.58 & 2.07 & n.a. \\
Tunisia & $(1971)$ & 2.08 & 0.79 & 1.28 & 3.31 \\
Uruguay & $(1968)$ & n.a. & n.a. & 1.53 & 1.45 \\
\hline
\end{tabular}

Notes: Ivory Coast: Modern sector ratios are relative to modern sector employment in modern sector HOS importables; total employment (including artisans) is relative to employment in all HOS importables.

South Korea: Data are per unit of output.

Tunisia: Crude and refined oil are excluded from the individual exportable estimates; manufactured consumer goods were used for protected imports; import-competing sectors exclude those with negative IVA.

Uruguay: Data are for total workers per DVA, [5, Chap. 11, Table 12]. 
It is perhaps somewhat more surprising that in those cases for which data were available, NRB exports turned out to be more labour-using per unit of DVA than were HOS import-competing industries. ${ }^{12}$ In most cases, this result is simply a reflection of the fact that most NRB exports originate from the agriculture sector, in which output per worker is very low and techniques of production are very labourintensive. There are important and unresolved questions about the functioning of rural labour markets. The predominance of NRB, labour-intensive, exports in the total export bundle is an important reason why labour coefficients should be estimated separately for NRB and HOS goods.

The reader will have observed that data for South Korea were not included in Table 2. The reason for this omission is that estimates of the factor content of South Korea's trade have been made in terms of labour and capital in puts per unit of output, rather than per unit of DVA. Hong's estimates for South Korea are for total trade, including both NRB and other trade in one category, and are therefore not comparable to the other figures. Table 3 therefore reproduces the estimates by Westphal and Kim [13] of labour-capital ratios for manufacturing sectors only. In the light of South Korea's lack of raw materials, it is likely that there are few manufacturing sectors deriving their comparative advantage from raw material availability, so that the figures can be taken as representative of HOS categories.

Table 3

Factor Proportions in South Korea: 1960 to 1968

(labour-capital ratios)

\begin{tabular}{|c|c|c|c|c|}
\hline Manufacturing Sector & 1960 & 1963 & 1966 & 1968 \\
\hline Domestic Output & 2.97 & 2.89 & 2.67 & 2.64 \\
\hline Exportables & 2.72 & 3.02 & 3.24 & 3.55 \\
\hline Import-Competing Production & 2.09 & 1.93 & 1.98 & 2.33 \\
\hline
\end{tabular}

Source: $[13]$.

As can be seen, South Korea's manufactured exports were, on an average, less labour-intensive than her manufactures sold in the domestic market in 1960, although they were about one-third more labour-intensive than import-competing manufacturing. That year marked the start of the South Korean export promotion drive. By 1963, exports had increased their labour-intensity relative to importcompeting goods, and also relative to domestic output. By 1968 the labour-capital

${ }^{12}$ If the Tunisian figure is recomputed to include oil among NRB exports, the Tunisian NRB exports become an exception to the above statement. ratio in exporting had increased to 3.55 , while that in import-competing industries was 2.33: all manufacturing except that destined for the domestic market had increased its labour-capital ratio over the course of the shift to export promotion. ${ }^{13}$

Data for Hong Kong are also of interest, and are presented in Table 4. Hong Kong has virtually no raw materials, so that all exports can be regarded as HOS goods. In Hong Kong, as in South Korea, the domestic value-added-to-output ratio was substantially higher in import-competing industries than in export industries. In the South Korean case, this is in part a reflection of the fact that the authorities were

Table 4

Factor Proportion in Hong Kong's Trade

(per million Hong Kong dollars of trade, current prices)

\begin{tabular}{|c|c|c|c|c|}
\hline & \multicolumn{2}{|c|}{1962} & \multicolumn{2}{|c|}{1973} \\
\hline & Exports & $\begin{array}{c}\text { Import- } \\
\text { Competing }\end{array}$ & Exports & $\begin{array}{r}\text { Import } \\
\text { Competir }\end{array}$ \\
\hline \multicolumn{5}{|l|}{ Direct } \\
\hline Depreciation (HK \$000) & 34 & 49 & 55 & 71 \\
\hline Profits (HK \$000) & 303 & 290 & 223 & 315 \\
\hline Labour (man-years) & 265 & 279 & 74 & 60 \\
\hline Professional labour (man-years) & 0.87 & 1.98 & 0.56 & 1.10 \\
\hline \multicolumn{5}{|l|}{ Direct Plus Home Goods } \\
\hline Depreciation (HK \$000) & 34 & 47 & 60 & 74 \\
\hline Profits (HK \$000) & 301 & 290 & 263 & 346 \\
\hline Labour (man-years) & 244 & 256 & 68 & 56 \\
\hline Professional labour (man-years) & 1.44 & 2.59 & 0.85 & 1.36 \\
\hline
\end{tabular}

Source: [12].

${ }^{13}$ In correspondence, Hong offered an index of labour intensity of South Korean domestic output and exportables with $1960=100$. According to these data, labour intensity behaved as follows:

\begin{tabular}{|c|c|c|c|c|c|c|}
\hline & 1963 & 1966 & 1968 & 1970 & 1973 & 1975 \\
\hline $\begin{array}{l}\text { Domestic Output } \\
\text { Exportables }\end{array}$ & $\begin{array}{l}1.000 \\
1.026\end{array}$ & $\begin{array}{l}.553 \\
.884\end{array}$ & $\begin{array}{l}.610 \\
.873\end{array}$ & $\begin{array}{l}.500 \\
.670\end{array}$ & $\begin{array}{l}.382 \\
.460\end{array}$ & $\begin{array}{l}.333 \\
.263\end{array}$ \\
\hline
\end{tabular}

This pattern is generally consistent with the Westphal-Kim findings. By 1975 , subsidies to usin capital were an important component of the export incentive system. See Hong's discussion in [5]. 
very liberal in permitting exporters to import needed raw materials, but much more restrictive in their treatment of producers of goods destined for sale on the home market. In part, however, it may also reflect that both South Korea and Hong Kong have tended to find production for export most profitable in lines in which they could import raw materials without heavy transport costs. For activities where high transport costs precluded importing raw materials and intermediate goods, reliance upon domestic sources probably led to a competitive disadvantage in their trade.

Overall, the descriptive statistics of Tables 2, 3 and 4 support the proposition that HOS exportables, at least in the countries covered in the project, tend to be more labour-using than HOS import-competing production. This conclusion holds regardless of the impact of policy measures and factor market distortions upon factor proportions and the commodity composition of trade. To be sure, these statistics provide only a glimpse into the possible orders of magnitude of the potential impact on employment of a shift in trade strategy. They are nonetheless suggestive that a shift towards an outward oriented trade strategy would generally not be consistent with the goal of increasing employment opportunities. ${ }^{14}$

The country authors' estimates of the separate coefficients for skilled, unskilled and managerial labour inputs are reported in Table 5. There appear to be large and systematic differences between skill coefficients for HOS exportable and HOS import-competing industries. They are more pronounced than differences in overall labour coefficients.

The definition of skills changed from country to country, depending on data availability. Since coefficients generally pertained to urban sector production in HOS exporting and import-competing industries, it is a reasonable conjecture that, in most cases, the term "unskilled" labour refers to individuals in the least-educated or least trained category eligible for employment in any modern sector activity. It is probable that some literacy was required.

From Table 5, the picture that emerges is that unskilled labour coefficients in HOS import-competing industries are even smaller relative to HOS exporting industries than are total labour coefficients. In each case for which a breakdown is available, the unskilled labour coefficient ratio for exportables exceeds that for total labour. Likewise, in all cases the skilled labour coefficient in import-competing industries exceeds that in exportable industries. ${ }^{15}$

Thus, based on the evidence from the countries covered in the project, it appears that not only are HOS exportables generally more labour-using than HOS

${ }^{14}$ The pattern of factor demand implied by alternative trade strategies appears in general to be little affected whether direct or direct-plus-home-goods-indirect-coefficients are used.

${ }^{15}$ Data from Hong Kong show a similar picture. The ratio of professional labour in import-competing to exportable industries was 1.77 . Nogues estimated a higher skill coefficient of Argentine import-competing industries by 27 percent when a skill classification was used.
Table 5

Ratio of Direct Coefficients in HOS Exportable to HOS Import-Competing Industries per DVA Managerial, Skilled, and Unskilled Labour

\begin{tabular}{llcll}
\hline Countries & Period & $\begin{array}{c}\text { Unskilled } \\
\text { Labour }\end{array}$ & $\begin{array}{c}\text { Skilled } \\
\text { Labour }\end{array}$ & $\begin{array}{c}\text { Managerial } \\
\text { Labour }\end{array}$ \\
\hline Argentina & 1973 & n.a. & 1.268 & n.a. \\
Brazil & 1959 & n.a. & 0.954 & n.a. \\
Chile & 1971 & n.a. & 0.978 & n.a. \\
Colombia & $1966-68$ & n.a. & 0.842 & n.a. \\
Indonesia & 1973 & 2.174 & 0.519 & 1.231 \\
Ivory Coast & 1971 & 2.273 & 0.810 & 1.100 \\
Tunisia & 1972 & 1.510 & 0.960 & 0.835 \\
Uruguay & 1972 & 1.582 & 0.810 & n.a. \\
\hline
\end{tabular}

Colombia: Unskilled workers are blue-collar workers.

Indonesia: "Unskilled" is sum of "male operative" and "female operative" man-days.

Ivory Coast: Modern sector HOS coefficients from [5, Chap. 6, Table 11]. Data refer to modern sector HOS exportables and import-competing industries.

Uruguay: Skilled workers are "white-collar" workers.

import-competing goods, but their input of unskilled labour is greater than that of import-competing industries by an even wider margin, while import-competing industries place a greater demand on the skilled labour forces in those countries.

There are a priori grounds for expecting differences in factor intensity both for exports by destination and for imports by source. This expectation was in general borne out by the results of the individual country authors. Table 6 provides the basic data. In some instances, notably in those of Indonesia and Hong Kong, such a large fraction of exports is destined for developed countries that it is difficult to attach significance to the separate coefficients. In other cases, however, the trade with other developing countries is sizable, and differences in factor proportions considerable. For Chile, for example, about half of all HOS exports are destined to other Latin American Free Trade Area (LAFTA) countries. Chile's exports to developed countries have a labour coefficient of 61 , contrasted with 29 for exports to the LAFTA region. Uruguay has sizable exports to LAFTA and, again, these exports appear to be far less labour-intensive than exports to developed countries. For Brazil, too, LAFTA exports are less labour-intensive than other exports. For the Ivory Coast and Pakistan, there are also pronounced differences on the importcompeting side: for those two countries, production competing with imports from 
other LDCs was far more labour intensive than was production competing with imports originating from developed countries.

The orders of magnitude of difference in labour intensity according to export destination are in some cases as great as the differences between overall labour coefficients for HOS exportables and import-competing production. For Chile, for example, reducing one unit of DVA of exportable production for developed countries and replacing it with one unit of DVA of import-competing production would entail a net "loss" of 18 jobs, or a reduction of 28 percent in employment. By contrast, contraction of a unit of DVA of HOS exportable production for other

Table 6

\section{Direct Labour Coefficients per DVA} by Direction of Trade

\begin{tabular}{|c|c|c|c|c|c|c|c|}
\hline \multirow{2}{*}{ Countries } & \multirow{2}{*}{ Period } & \multicolumn{3}{|c|}{ HOS Exportables } & \multicolumn{3}{|c|}{ HOS Import Competing } \\
\hline & & DC & LDC & Total & $\mathrm{DC}$ & $\mathrm{LDC}$ & Total \\
\hline Argentina & 1973 & 164 & 147 & n.a. & n.a. & n.a. & n.a. \\
\hline \multirow[t]{3}{*}{ Brazil } & 1959 & 115 & 141 & 115 & n.a. & n.a. & 128 \\
\hline & 1970 & 89 & 79 & 87 & n.a. & n.a. & 71 \\
\hline & 1972 & 109 & 78 & 87 & n.a. & n.a. & 71 \\
\hline Chile & $1966-68$ & 61 & 29 & 34 & 43 & 43 & 43 \\
\hline \multirow[t]{2}{*}{ Colombia } & 1970 & 28 & 21 & 24 & n.a. & n.a. & n.a. \\
\hline & 1973 & 32 & 24 & 29 & n.a. & n.a. & n.a. \\
\hline Hong Kong & 1973 & 24 & 21 & 24 & 18 & 15 & 17 \\
\hline Indonesia & 1971 & 2176 & 2149 & 2175 & 994 & 1117 & 1038 \\
\hline Ivory Coast & 1972 & n.a. & n.a. & 2488 & 1520 & 1743 & 1652 \\
\hline Pakistan & $1969-70$ & 90 & 88 & 188 & 70 & 120 & 71 \\
\hline Thailand & 1973 & 22 & 20 & 22 & 11 & 22 & 11 \\
\hline Uruguay & 1968 & 441 & 239 & 366 & n.a. & n.a. & 238 \\
\hline
\end{tabular}

Data are from [5, Chap. 2, Table 14] and represent total labour requirements per DVA. The numbers for developed countries are an unweighted average of EEC and U.S. and Canada coefficients while the LDC numbers refer to LAFTA trade.

Colombia: DC figure is an unweighted average of "United State" and "other developed countries".

Indonesia: Total man-days from [5, Chap. 5, Table 15].

Ivory Coast: Data (expressed in man-hours) taken from Table 11 and represent total labour requirements per DVA. HOS import-competing industries refer to imports requiring protection. No breakdown of HOS exportable trade between DCs and LDCs was made due to the
Excludes PCB exports [5, Chap. 7,Table 12].

Thailand: Data supplied by Akrasanee for HOS Import-Competing goods, exclusive of alcoholic beverages and tobacco, gives 21 for DCs and Total.
LDCs (almost entirely LAFTA) and replacement with a unit of DVA of domestic import-competing production would result in a change from 29 jobs to 43 jobs an increase of almost 50 percent in employment. To be sure, the coefficients are not necessarily perfect indicators of what would happen with an alteration in trade strategy, but the orders of magnitude are sufficient to suggest that it matters not only which sectors - NRB or HOS - trade originates in, but also which countries are the trading partners. For Chile, an export-promotion strategy based upon the LAFTA market would probably result in a shift towards less labour-using industries, while an export promotion strategy based upon trade with the developed countries would have the opposite result.

\section{DISTORTIONS IN WAGE-RENTAL RATIOS}

Exchange rate overvaluation, coupled with the reluctance of policy makers to impose duties on imports of capital goods, has contributed to low capital costs under import-substitution regimes. There are five countries where authors had data to estimate the order of magnitude involved - Argentina, Brazil (in the 1950s), Chile, Pakistan, and Tunisia. In all cases, the authors' estimates of the order of magnitude of the subsidy from the trade regime implicit in the pricing of capital goods was in the range of 30-40 percent, by no means a negligible amount.

Under export promotion, the picture has been different. There, the currency has been fairly realistically valued, so that little opportunity for undervaluation of capital goods has arisen. Rather, the experience has tended to be that domestic incentives, such as low-interest loans, are accorded to exporting industries.

In contrast to trade regimes, credit rationing, or at least provision of some low-interest loans, was a feature of almost all countries, both export-promoting and import substitution. ${ }^{16}$ One or more forms of subsidy to the use of capital or imported capital equipment were found in all cases analyzed. The implicit subsidy involved appears to have been substantial, exceeding the estimated magnitude of cost reduction associated with currency overvaluation in some cases. Even in South Korea, interest subsidies appear to have become a distortionary element of some magnitude, especially in the late 1970 s, after the period covered by Hong.

Two additional conclusions emerged. First, in many instances reductions in the cost of using capital equipment were granted for firms carrying out objectives associated with the trade regime. Thus, the Ivory Coast's "priority industry" status, which provided loans at preferential rates and tax exemptions, was a means whereby the authorities could induce production of the types of commodities they wished. Brazil's Banco Nacional de Desenvolvimento Economico (BNDE) loans seem

${ }^{16}$ Hong Kong is an exception. It is arguable whether Brazil's BNDE loans constitute credit rationing. And the evidence is simply not available for Chile or Colombia. 
to have been destined largely for some of the sectors associated with her exportpromotion drive. These, and other, examples provide yet another strong indication that one cannot divorce analysis of the trade regime and its effects from consideration of conditions in domestic markets.

Secondly, low-interest loans and currency overvaluation are in many ways substitutes in so far as they affect the cost of using imported capital equipment. In some cases, such as that of Pakistan, they interact to provide very large reductions in cost. In principle, however, either an overvalued exchange rate or availability of credit at below-market borrowing rates can provide strong incentives for use of capital-intensive techniques.

Turning to labour market distortions, a first, and perhaps most important, conclusion to be drawn is how little is known about conditions in labour markets in the LDCs. In part, this is because the data requirements for a satisfactory analysis of these phenomena are inherently demanding, and definitive data sets are hard to come by. Nonetheless, it is clear that further research on determinants of wage structure is called for, and that the results would substantially enhance our understanding of a number of important phenomena in developing countries. A second conclusion, necessarily considerably more impressionistic than the first, is that the extent and magnitude of labour market distortions are considerably smaller than were anticipated and that mispricing of capital goods and capital services appears to be proportionately larger than that of labour services.

The most frequently-encountered intervention in labour markets is the imposition of social insurance payments and other charges upon the employment of labour. Large firms in the formal sector are obliged to pay these charges while those in the informal sector are able to avoid them. That pattern appears to be the case in Argentina, Brazil, Colombia, the Ivory Coast (in combination with minimum wage legislation), and perhaps in Thailand. The same type of differential in unskilled wages appears in Tunisia between government enterprises and small-scale employers, but the causal mechanism is less clear.

At least until the early 1970s, the impact of these regulations appears to have been restricted to the fomal sector and unskilled labour. If one is focusing upon the impact of alternative trade strategies upon employment, however, it is precisely the unskilled workers, and the ability of firms and industries using them intensively to compete on international markets, that must be the focal point of analysis. It is perhaps noteworthy that both Brazil and South Korea, during their periods of rapid export growth, had few interventions with wage determination and, in the Brazilian case, those that there were appear to have diminished considerably in importance over the period. Likewise, the countries where there are sizable differences in labour coefficients according to trade categories - notably Indonesia, Pakistan, and, to a lesser extent, Thailand - are countries where there has not been, at least during the period covered by the analysis, any significant degree of intervention in wage determination for unskilled workers.

\section{CONCLUSION: TOTAL SIZE OF FACTOR COST DISTORTIONS}

With the caveat that they are only of orders of magnitude, estimates of the degree to which wage-rental rations diverged from those that would have prevailed under well-functioning factor markets can be assembled from the country studies.

Table 7 provides the data. The numbers would have greater comparability if one could provide estimates of the variance of these cost-increasing and costreducing distortions, as well as their mean, but it is not possible to do so. The comparability across countries is, therefore, extremely limited. For example, Nogues estimated that the reduction in costs of capital due to the trade regime in Argentina when all capital goods were imported was on the order of 40 percent - remarkably close to the estimates from Chile, Pakistan and Tunisia (as well as Brazil in her import-substitution period). However, for Argentine firms there was an offset in that domestically-produced capital goods cost more than imported ones would have at equilibrium. Thus, the average 8 percent figure calculated by Nogues represents what the net impact would be on a manufacturing firm employing imported and domestic capital goods in the proportions used by the sector as a whole. In reality, there were undoubtedly firms. importing almost all their capital equipment, and others relying almost entirely on domestic capital goods. Whether Argentina's 8 percent average reduction in capital cost due to the trade regime represents more or less of a distortion given the presence of the domestic capital-goods-producing import-substitution industries than the 38 percent reduction in Pakistan, where almost all capital goods were imported (and where, therefore, the reduction was probably relatively uniform and across-the-board) is an open question.

Before examining the data in Table 7, one other comment is in order. That is, a distortion affects the wage-rental ratio throughout the economy. If, for example, one sector has a tax imposed upon the utilization of a particular factor of production, the return to that factor of production and all others will be affected, both in the tax-impacted sector and in the rest of the economy. It is well known that there are conditions under which raising the price of, e.g. labour, to a particular sector can lower the real wage to workers in both sectors. In the empirical estimates that follow, no account is taken of this phenomenon, and it is assumed that the wage-rental ratio in the sectors not subject to any distortions is unaffected by their presence elsewhere in the economy. In a sense, the estimates of the magnitude of distortions presented here are really an estimate of the differential in relative factor prices between sectors subject to distortions and sectors not subject to distortions.

Turning then to the data in Table 7, it is apparent that labour market factors, the trade regime, credit rationing, and tax systems, all contributed to raising the wagerental ratio for firms subject to them. There is no single pattern of relative importance among these factors, however. Pakistan, which appears to have the highest degree of implicit subsidization to the use of capital-intensive techniques, has 
Table 7

Percentage Distortions in Labour and Capital Costs from Various Sources

\begin{tabular}{|c|c|c|c|c|c|c|c|}
\hline \multirow{2}{*}{ Countries } & \multirow{2}{*}{\multicolumn{2}{|c|}{$\begin{array}{c}\text { Percentage } \\
\text { Year Increase in } \\
\text { Labour Costs }\end{array}$}} & \multicolumn{4}{|c|}{$\begin{array}{l}\text { Percentage Reduction in } \\
\text { Capital Costs due to }\end{array}$} & \multirow{2}{*}{$\begin{array}{c}\text { Percentage } \\
\text { Increase in } \\
\text { Wage-Rental } \\
\text { Ratio }\end{array}$} \\
\hline & & & $\begin{array}{c}\text { Trade } \\
\text { Regime }\end{array}$ & $\begin{array}{c}\text { Credit } \\
\text { Rationing }\end{array}$ & Other & Total & \\
\hline Argentina & 1973 & 15 & 8 & 9 & n.a. & 17 & 38 \\
\hline Brazil & 1968 & 27 & 0 & 4 & n.a. & 4 & 31 \\
\hline Chile & $1966-68$ & 8 n.a. & 37 & n.a. & n.a. & n.a. & n.a. \\
\hline Hong Kong & 1972 & 0 & 0 & 0 & 0 & 0 & 0 \\
\hline Ivory Coast & 1971 & 23 & 0 & $3^{a}$ & $12^{\mathrm{a}}$ & 15 & 45 \\
\hline Pakistan & $1961-64$ & 0 & 38 & 53 & 10 & 76 & 316 \\
\hline South Korea & 1969 & 0 & 0 & 8 & 2 & 10 & 11 \\
\hline Tunisia & 1972 & 20 & 30 & 6 & n.a. & 36 & 87 \\
\hline
\end{tabular}

Note: No quantitative estimates are available for Colombia, Indonesia, Thailand or Uruguay. ${ }^{a}$ Estimates based on differentials given in [5, Chap. 6, Table 15] and reproduced in Section 7.2 .6 of $[7]$.

(or, more accurately, had) a relatively free labour market. By contrast, Tunisia, like the Ivory Coast, appears to have had cost differentials of virtually all types. Yet the rank order of the estimated magnitude of distortion seems to be independent of the number of different types of distortions identified. Thus, Nogues was able to quantify labour market interventions of several types as well as trade regime and credit rationing influences upon capital costs. Yet, his estimates for Argentina fall far below Nabli's Tunisian estimates where the same pattern of pervasive distortion seems to have existed.

What seems clear, even from these impressionistic data, is that the exporting countries - Hong Kong, South Korea, Brazil and, to a lesser extent, the Ivory Coast - had relatively lower levels of factor market distortions than did the import-substitution countries, with the possible exception of Argentina. Even there, the Argentine data represent perhaps more of an average among highly-subsidized and unsubsidized firms.

A second conclusion, probably not unrelated to the first, is that currency overvaluation and favourable treatment of capital-goods imports were potent sources of lowering the costs of capital utilization for firms eligible to import. For Argentina, Chile, Pakistan and Tunisia, as well as for Brazil in her import-substitution days, this source of underpricing of capital goods was judged to be important.
Credit rationing at subsidized interest rates is estimated by Hong and Guisinger to have constituted a major source of underpricing of capital services. Finally, social insurance taxes have driven a wedge, again of about 20-30 percent, in the price of labour between firms and sectors subject to the taxes and other activities within the economy.

Each of these sources of pricing disparity between firms and sectors by itself could significantly have affected incentives, but together the effects may have been fairly powerful. All of them work in the same direction, to induce lower capital costs, and higher labour costs than would be chosen at appropriate shadow prices. Distortions of the order of magnitude reported by the country authors must surely have reduced whatever comparative advantage these countries might otherwise have had in labour-intensive exports.

This raises a fundamental empirical question, about which there is little information to date. That is: how large are the differences in "natural" wage-rental ratios that would be observed under an efficient allocation of world resources? If, in fact, Pakistan's optimal wage-rental ratio is one-fiftieth of that of her major trading partners, then the fact that trade and domestic policies distorted that ratio by a factor of four need not have significantly adversely affected her potential pattern of commodity trade. If, on the other hand, the optimal wage-rental ratio in Pakistan were one-fifth of that of her major trading partners, distortions of the order of magnitude estimated by Guisinger [ 5 , chap. 7] would have had a severe impact on the potential for gains from trade. Moreover, if there were "neighbouring" countries in the chain of comparative advantage with fewer distortions in factor markets than those in Pakistan, one can again imagine that distortions within Pakistan could have adversely affected the scope for profitable (and economic) expansion of exports.

\section{RELATIVE IMPORTANCE OF TRADE STRATEGY AND FACTOR MARKET DISTORTIONS}

Finally, one can estimate the combined potential impact of choice of trade strategy, within-strategy inefficiencies, and factor market distortions on the increase in the demand for labour in the project countries. Such estimates are, of course, based on a number of assumptions, not to mention imprecise data.

The estimates are contained in Table 8. There, the observed labour coefficients in HOS exportables and import-competing industries (with the labour coefficient in import-competing industries set equal to 100) are given in Column (2). Columns (3) and (4) then indicate the percentage increase in the labour coefficient that might have been expected if there were no domestic factor market interventions, and no incentives associated with the trade strategy that lower the cost of using capital-intensive techniques of production. Column (5) then gives the estimate of the extent to which the labour coefficient might increase by altering the commodity 
composition of output under the trade strategy indicated. Finally, Column (6) gives the coefficient that would be observed if all sources of distortion were removed.

Table 8

Sources of Potential Increase in Labour Coefficients

\begin{tabular}{|c|c|c|c|c|c|}
\hline \multirow{2}{*}{$\begin{array}{c}\text { Countries } \\
\text { (with Reference } \\
\text { Years) }\end{array}$} & \multirow{2}{*}{$\begin{array}{c}\text { Observed } \\
\text { Direct } \\
\text { Labour } \\
\text { Coefficient }\end{array}$} & \multicolumn{3}{|c|}{ Increase (percent) if there is } & \multirow{2}{*}{$\begin{array}{c}\text { Potential } \\
\text { Coeffi- } \\
\text { cient }\end{array}$} \\
\hline & & $\begin{array}{l}\text { No domestic } \\
\text { factor market } \\
\text { intervention }\end{array}$ & $\begin{array}{c}\text { No Trade } \\
\text { Strategy } \\
\text { Distortion }\end{array}$ & $\begin{array}{c}\text { No within- } \\
\text { strategy } \\
\text { Inefficiency }\end{array}$ & \\
\hline (1) & (2) & (3) & (4) & (5) & (6) \\
\hline
\end{tabular}

\section{A. HOS Import-Competing Industries}

\begin{tabular}{|c|c|c|c|c|c|c|}
\hline Argentina & 1973 & 100 & 18 & -8 & 0 & 110 \\
\hline Brazil & 1970 & 100 & 15 & n.a. & n.a. & 115 \\
\hline Chile & $1966-68$ & 100 & n.a. & 7 & n.a. & 107 \\
\hline Colombia & 1970 & 100 & n.a. & n.a. & 10 & 110 \\
\hline Indonesia & 1971 & 100 & n.a. & n.a. & 66 & 166 \\
\hline Ivory Coast & 1972 & 100 & 25 & 0 & 12 & 140 \\
\hline Pakistan & $1969-70$ & 100 & 271 & 0 & n.a. & 271 \\
\hline South Korea & 1968 & 100 & 8 & 0 & 0 & 108 \\
\hline Tunisia & 1971 & 100 & 17 & 38 & 58 & 244 \\
\hline \multicolumn{7}{|c|}{ B. HOS Exportable Industries } \\
\hline Argentina & 1973 & 130 & 18 & -8 & 0 & 143 \\
\hline Brazil & 1970 & 207 & 15 & n.a. & n.a. & 238 \\
\hline Chile & $1966-68$ & 80 & n.a. & 7 & 68 & 144 \\
\hline Colombia & 1970 & 170 & n.a. & n.a. & 24 & 210 \\
\hline Indonesia & 1971 & 209 & n.a. & n.a. & 0 & 209 \\
\hline Ivory Coast & 1972 & 135 & 25 & 0 & 0 & 169 \\
\hline Pakistan & $1969-70$ & 142 & 271 & 0 & n.a. & 384 \\
\hline South Korea & 1968 & 100 & 8 & 0 & 0 & 108 \\
\hline Tunisia & 1971 & 128 & 17 & 38 & 0 & 198 \\
\hline
\end{tabular}

Notes: 1. Ivorian estimates are for modern sectors only.

2. Corbo-Meller estimates for capital costs refer to direct plus home goods indirect, [7,Table 8-8].

. An estimated labour share of 0.3 was used in relying on data in [7, Table 8-9].

4. For Chile, Within-strategy inefficiency within exports taken to be LDC exports.
As can be seen, the estimated increments in labour coefficients are quite sizable. For example, if the underlying assumptions and data are correct, Tunisia might have generated about twice as many employment opportunities as, in fact, were generated under the import-substitution strategy. By and large, the estimates suggest that there is more scope for improving the efficiency of resource allocation among import-competing industries than there is among HOS exportable industries. Only for Chile and Colombia do the estimates indicate opportunities for greater proportional potential increases in exportables. In both those instances, this reflects the fact that exportables under the import-substitution strategy in effect at the time of the estimates probably constituted a response to import-substitution incentives. In the Chilean case, especially, it was the incentives under import-substitution to export out of import-substitution output to LAFTA that account for the sizable potential for increasing employment in exportables. This could have been realize simply by shifting towards greater emphasis on exports destined for developed countries.

Table 9 summarizes the findings from Table 8, and then in addition provides an estimate of the proportionate differences in labour coefficients under alternative trade strategies. For example, the estimates suggest that the Ivory Coast could have realized an increase in employment within HOS exportable industries of 25 percent, and within import-competing industries of about 40 percent. In addition, shifting a thousand FCFA of domestic value added from HOS import-competing production to exportable production (within the modern sector) would have permitted a 21 -percent increase in the demand for labour per unit of shift.

These numbers by no means indicate the extent of possibilities for a shift in the demand for labour. In particular, if substitution of labour for capital were encouraged by the dismantling of incentives for employing capital, there could presumably be additional investment in some tradable activities; the increment in the demand for labour that might arise from that source is not considered here, partly because the estimates are already conjectural enough, and partly because the same "released capital" effect would occur regardless of which of the three sources of increased demand for labour evaluated in Table 9 in fact took place. For the latter reason, there is some basis for believing that the magnitude of the numbers in Table 9 already reflects the relative potential for increasing the demand for labour within existing trade strategies and also by altering trade strategies.

Comparisons across countries, based on the data in Table 9, should be made with care. In particular, the low estimated potential for South Korea is a misleading figure, given knowledge of the rapid expansion of manufacturing employment that occurred following that country's switch in trade strategy. Indeed, the evidence suggests that the South Korean emphasis on export promotion resulted in a fairly efficient pattern of production within import-competing as well as exportable industries, which had already been realigned by 1968. Thus, comparison of the 
Table 9

\section{CONCLUSIONS}

Potential Sources of Increased Demand for Labour

\begin{tabular}{|c|c|c|c|}
\hline \multirow{5}{*}{ Countries } & \multirow{5}{*}{ Year } & Increased in Labour & \multirow{5}{*}{$\begin{array}{c}\text { Shift } \\
\text { in } \\
\text { Strategy }\end{array}$} \\
\hline & & Coefficient at & \\
\hline & & Constant Value & \\
\hline & & Added & \\
\hline & & IC & \\
\hline
\end{tabular}

\section{(Percent of Observed Labour Coefficient)}

\begin{tabular}{llrrr} 
Argentina & 1973 & 10 & 10 & 30 \\
Brazil & 1970 & 15 & 15 & 107 \\
Chile & $1966-68$ & 80 & 7 & 34 \\
Colombia & 1970 & 24 & 10 & 91 \\
Indonesia & 1971 & $\mathrm{n} . \mathrm{a}$. & 66 & 26 \\
Ivory Coast & 1972 & 25 & 40 & 21 \\
Pakistan & $1969-70$ & 171 & 171 & 41 \\
South Korea & 1968 & 8 & 8 & 0 \\
Tunisia & 1971 & 55 & 144 & 23 \\
\hline
\end{tabular}

Brazilian potential for increasing the demand for labour through shifting trade strategies (which was presumably largely realized during the late 1960s and early 1970s) with the South Korean potential is unwarranted.

Of greater interest is the extent to which inferences can be drawn from the comparative magnitudes within countries. For Tunisia, the greatest potential source of increase in the demand for labour appears to arise from rationalization of the import-competing sectors of the economy. For Pakistan, removing incentives for employing overly capital-intensive techniques would appear to offer even greater promise of shifting the demand for labour upward than does a shift in trade strategy. To be sure, Pakistan could, by shifting trade strategies and removing incentives to employ capital-intensive techniques, realize an even greater upward shift in the demand for labour. That is, if the labour-value added ratio in Pakistani HOS exporting industries rose by 171 percent in response to the abandonment to use capital intensive techraques and Pakistan simultaneously shifted resource towards exportables, the scope for increased employment would be 1.41 times 1.71 , or 2.41 , as domestic factors of production allocated at the new factor proportions in exportables would result in a labour-value added ratio 2.41 times as high as the preexisting labour-value added ratio in HOS import-competing industries. For all the countries, except possibly South Korea in 1968, there was clearly sizable room for increasing the demand for labour consistent with improved resource allocation and generally through more than one avenue.
Perhaps the most striking findings emerging from the Trade Strategies and Employment Project were that, on the one hand, despite factor market conditions, developing countries' manufactured exports tend to exhibit the factor intensity consistent with their endowment, and that, on the other hand, the scope for further increasing the demand for labour through both trade policies and realignment of domestic factor market incentives is sizable.

Thus, in answer to the questions initially raised in the project, there does not appear to be any conflict between objectives associated with more rational resource allocation and increasing the demand for labour, especially unskilled labour. Indeed, the degree to which the project countries' exportables were intensive in the use of unskilled labour was one of the important conclusions to emerge from the country studies.

An equally striking finding was the extent to which our knowledge and understanding of factor markets in developing countries are imperfect. Analysis of the interaction between trade strategies and domestic factor markets was generally constrained more by a lack of data and analyses of domestic factor market conditions than by data and analyses of trade strategies.

The project has raised as many questions as it has answered, but an analysis of most of those questions will require prior intensive examination and understanding of the functioning of domestic factor markets. The evidence on the size of the divergence in capital-labour costs, between formal and informal sectors of the economy, is striking. Although the estimates given above provide some basis for assessing the effects of such differences, there is a great deal of work remaining to be done in understanding factor market interventions and their effects. The orders of magnitude are so large that it is at least plausible that low observed elasticities of employment with respect to industrial output may be explicable in terms of factor market interventions. Regardless of whether those distortions are partly or almost entirely to blame for failure of employment opportunities to grow, finding ways to remove incentives for using capital-intensive techniques is surely one component of any effort to increase real incomes and employment opportunities.

The evidence from the country studies and from the project as a whole strongly suggests that there are potential gains to be had in resource allocation and employment from shifting to an outward-oriented trade strategy. Moreover, the size of the potential gain very much depends on the degree to which factor markets function appropriately. While alteration of the trade strategy itself may remove one source of distortion in costs of using capital-intensive techniques, it is clear that credit rationing, tax structures, and labour legislation also play important roles.

In many of the project countries, provision of appropriate factor market incentives to producers could have resulted in significantly increased demand for unskilled labour, given the existing trade strategy. Likewise, alteration of the trade 
strategy could have resulted in sizable increases in the demand for unskilled labour, even in the presence of inappropriate relative prices for use of factors of production. Obviously, however, the greatest potential for employment gain is in those situations where the shift in policy realigns incentives in both the domestic factor market and the trade regime. The extent to which there may have been interaction between inward-oriented trade strategies and factor-market distortions, both leading to high capital-output ratios and low rates of increase in the demand for labour, is striking.

Moreover, the income-distribution implications of the findings seem to accord fairly well with the proposition that inward-oriented trade strategies and measures which increased incentives for using capital-intensive techniques probably contributed to a less equal income distribution than might otherwise have been observed. The fact that HOS exportable industries tend to be relatively intensive in the use of unskilled industrial labour suggests that additional employment in those industries would increase the rate at which the urban sector could absorb new entrants to the labour force. To be sure, in so far as removal of labour-market legislation might reduce the real incomes of industrial workers, there would tend to be a partial offset; however, in most of the countries covered in the project, employed industrial workers were a small elite receiving relatively high earnings at the expense of fewer employment opportunities in the industrial sector and lower earnings for those unable to find employment within it.

\section{REFERENCES}

1. Chenery, Hollis B., and Michael Bruno. "Development Alternatives in an Open Economy: The Case of Israel". Economic Journal. Vol. 72. March 1962. pp. 79-102.

2. Eckaus, Kichard S. "The Factor-proportions Problem in Underdeveloped Areas”. American Economic Review. Septemebr 1955.

3. Harris, John R., and M. P. Todaro. "Migration, Unemployment and Development: A Two-sector Analysis". American Economic Review. Vol. 60. March 1970. pp. 126-142.

4. Krueger, Anne O. Foreign Trade Regimes and Economic Development: Liberalization Attempts and Consequences. Cambridge: Ballinger Press for the NBER. 1978.

5. Krueger, Anne O., Hal B. Lary, Terry Monson and Narongchai Akrasanee (eds.). Trade and Employment in Developing Countries, 1: Individual Studies. Chicago: University of Chicago Press for the NBER. 1981.

6. Krueger, Anne O. (ed.). Trade and Employment in Developing Countries, 2: Factor Supply and Substitution. Chicago: University of Chicago Press for the NBER. 1982.
7. Krueger, Anne O. Trade and Employment in Developing Countries, 3: Synthesis and Conclusions. Chicago: University of Chicago Press for the NBER. (Forthcoming)

8. Lewis, W. Arthur. "Economic Development with Unlimited Supplies of Labour”. The Manchester School. May 1954.

9. Nogues, Julio. "Trade Distortions, and Employment in the Argentine Manufacturing Sector”. Ph.D. thesis, University of Minnesota. 1980.

10. Sen, Amartya. Employment, Technology and Development. Oxford: Clarendon Press. 1975.

11. Srinivasan, T. N., and Jagdish N. Bhagwati. "Shadow Prices for Project Selection in the Presence of Distortions: Effective Rates of Protection and Domestic Resource Costs". Journal of Political Economy. Vol. 86, No. 1. February, 1978.

12. Sung, Yung Wing. "Factor Proportions and Comparative Advantage in a Trade-dependent Economy: The Case of Hong Kong”. Ph.D. thesis, University of Minnesota. 1979.

13. Westphal, Larry E., and Kwang Suk Kim. Industrial Policy and Development in Korea. Washington, D.C. : World Bank. August 1977. (World Bank staff working paper No. 263) 